\title{
FOREIGN PATENTS: OPPORTUNITIES AND DANGERS FOR THE GENERAL PRACTITIONER
}

\author{
Courtland Peterson*
}

T $N$ THE current age of increasing legal specialization, a paper on 1 patenting abroad aimed at the ordinary practitioner of law may seem to be at least a mild form of heresy. Most American lawyers have a time-tested method of dealing with clients who wish to consult on patent problems: "Please see a patent attorney." The worth of that advice will not be disputed here; quite the contrary. What this paper does suggest, however, is that the lawyer who wants to serve his clients well must develop and retain a breadth of understanding of his clients' affairs. Particularly if he represents clients interested in any type of manufacture, then such a broad understanding necessarily includes at least a basic knowledge of both the dangers and the opportunities which lurk in the relation between domestic and foreign patents.

Two examples will clarify this thesis. First, suppose that $A$, a manufacturer, conceives and develops an invention in his small factory. $A$ consults his attorney, $L$, who refers him to a patent lawyer, $P$. $A$ assures $P$ that all of his products are marketed domestically, that he does not have the capital to expand into broader fields, and that he has no interest in foreign patenting. $P$ proceeds to file for a United States patent. Suppose, however, that $L$ is alert and informed. He knows that $A$ 's chief competitor is a large concern, $B$, which does both a domestic and foreign business. $L$ recognizes at once that one of the principal economic values of the invention may consist in a license of the patent to $B$, and that the value of such a license to $B$ may depend, to a large extent, on protection under foreign as well as under domestic patents. But unless $A$ acts swiftly, the issue of a foreign patent may be barred by time limitations, and a substantial portion of the market value of the license may thereby be lost.

As a second example, suppose that an American firm has developed

* B.A., LL.B., University of Colorado; Doctorandus, University of Leiden, Netherlands; Foreign Law Fellow, University of Chicago; presently studying Comparative Law, University of Freiburg, Germany; member of the Colorado bar; recently appointed Assistant Professor of Law, University of Colorado. 
a new process of manufacture. Because implementation of the process would require extensive changes in the domestic plant, the owner of the firm decides to try out the process in a branch plant which is presently being established in Europe. Neither the owner nor his counsel have extensive experience with foreign branches, and the opening of the new branch has been undertaken principally to protect markets in the new Common Market area. In order to safeguard the new process, an application for patent is filed in the country where the branch is located. All of these acts seem innocent enough, but the results can be startling:

(I) Unless the United States Commissioner of Patents can be persuaded to grant a retroactive license for the exportation of an invention, the owner of the American firm may be criminally liable, and issue of a patent in the United States is barred. ${ }^{1}$

(2) Even if a retroactive license is granted, issue of a patent in the United States is barred if the foreign patent was issued more than twelve months before application was filed in the United States; if twelve months have expired since the foreign application and the foreign patent has not yet been issued, the applicant may secure a United States patent only if he succeeds in delaying issue of the foreign patent until the United States patent has been both applied for and issued. ${ }^{2}$

(3) If the law of the foreign country where application was made requires publication of the application, and if more than twelve months have expired since such publication, issue of a United States patent on a subsequent application is barred whether or not the foreign patent has been (or ever is) issued. ${ }^{3}$

Of course, the decision to patent abroad, like the decision to patent domestically, depends primarily on a prediction of whether or not the invention under consideration has sufficient actual or potential economic value to justify the cost of patent counsel, fees, taxes, and other attendant expenses. Ordinarily, the inventor plans to use or produce the invention himself or to license this privilege to someone else. He may also decide to apply for a patent to protect present or potential markets, or in order to acquire a better bargaining position in dealing for licenses

\footnotetext{
${ }^{2}$ Patent Codification Act of 1952, 35 U.S.C. $\$ \S 184,185,186$ (1952). Under $\S 184$, the Commissioner of Patents is permitted to grant retroactive licenses where the foreign filing has occurred through "inadvertence," unless the invention relates to national security. Consult appendix.

${ }^{2} I d . \S \mathrm{IO2}(\mathrm{d})$; consult appendix.

${ }^{3} I d . \S 102(\mathrm{~b})$; consult appendix.
} 
from other patentees. ${ }^{4}$ Whatever the benefit may be that he seeks, the inventor must assign to the invention an economic value which may be weighed against the costs. In short, the inventor must make the economic decision to patent just as he would make any other business decision.

In order to make this decision intelligently, the inventor will obviously want to retain a patent lawyer in this country to advise him with respect to costs and feasibility of patenting. Frequently, he will want to apply for a United States patent even if the possibility of foreign patenting is discarded. His ordinary counsel, however, should have some insight into the problems involved in patent law, despite the fact that he will probably not be concerned with the drafting or submission of the patent application. As we have already seen, he may be in a better position to advise on the desirability of foreign patenting than patent counsel himself. He may be useful as a liaison between the inventor and foreign patent counsel, or between domestic and foreign patent counsel, thus extending his own practice in a lucrative and interesting way. Most important of all, the stringent time limitations and requirements of most patent statutes may affect not only the cost of patenting, but also patentability itself. The general practitioner should thus be informed of the nature of such provisions in order to guard his client's interests both before and after patent counsel is consulted.

An exhaustive study of many foreign patent systems is certainly more than can be asked of the ordinary practitioner. The alternative,

\footnotetext{
"A list of reasons for patenting abroad is given in ToulMiN, Handbook of PATENTs 535-37 (2d ed, 1954). One of the pressing problens of dontestic enforcement of the patent monopoly in the United States arises from the fact that infringement by foreign imports is not actionable except in a suit against the importer and the dealers to whom he distributes. Since wide distribution has usually occurred before the infringement is discovered, an expensive multiplicity of suits is often the price of enforcement. Special and even more difficult problems exist in the case of enforcement of process patents. DeLio \& Worth, A Review of Protection of Patent Interests fram Unfair Methods of Competition in Importation, 39 J. PAT. OFF. SOC'Y 282 (1957). Of course, amendment of the American statute to provide more adequate procedures roould be the most effective solution of this problem. In the absence of such amendment, DeLio and Worth suggest various remedies under the tariff laws. Another method of attack on the problem would be patenting at the probable source of the foreign products, so that an injunction against the producer himself might be obtained. The usefulness of such a device would, of course, depend not only on the ability of the inventor to predict sources of foreign competition, but also upon the attitude taken by the source country toward "paper patents." See also Graham, Footnotes on Foreign Patent Practice, $39 \mathrm{~J}$. PAT. OFF. SoC'Y 623, 628 (1957), where reasons for patenting abroad are classified as "offensive" and "defensive."
} 
at which this paper aims, is a study of the principles underlying patent law in general, complemented by a specific comparison of our law with that of another country to illustrate problems and differences. Special attention will be paid to time requirements. Because of its re-emergence as the dominant economic power of Europe, the foreign system considered will be that of the Federal Republic of Germany.

\section{I}

\section{Patent Systems in General}

\section{A. Basic Policy and Principles}

Dangerous as generalization can be, it may be asserted with considerable certainty that the basic policy underlying the patent law of most countries of the world consists of the desire to promote science and useful arts. This purpose is expressed in our own Constitution ${ }^{b}$ and has been recognized in other countries as well. ${ }^{6}$ The important thing to note is that patents are in the nature of rewards for inventiveness; patents are not in themselves the object sought by society, but are rather the method by which inventiveness is encouraged. Viewed in this light, the systems of various countries can be divided into two groups, according to the method by which rewards are administered. Most countries fall in the first group, which rewards the inventor by granting him a monopoly (patent) on the invention for a specified term. A few countries, principally communistic, form a second group, which encourages the inventor by cash awards or the grant of special privileges. ${ }^{7}$ Further consideration will be limited to the first, or patent, group.

Beyond this basic starting point, generalization becomes more difficult. The way in which patents are administered varies widely between countries and often depends on the nature of the national economy -that is, on whether industry and commerce are highly developed. Whatever the state of technology may be, however, it follows from the basic policy noted above that an inventor should not be rewarded with a monopoly unless he has produced something new and useful. ${ }^{8}$ The requirement of utility is neither very complex nor very difficult,

${ }^{5}$ Art. I, \& 8.

'Scher, Patents, Trademarks, and Copyrights 58 (1954).

"Id. at 60 .

${ }^{8} 35$ U.S.C. § 101 (1952); Patentgesetz vom 5. Mai 1936 (RGBI II 117) in der Fassung der Bekanntmachung vom I8. Juli 1953 (BGBl I 623), para. 1; consult appendix. 
because there are few discoveries that do not admit of some use ${ }^{9}$ and because the value of the reward (the patent-monopoly) depends on the usefulness of the invention. ${ }^{10}$ The requirement of newness is a much more difficult question.

Newness may be viewed from either a subjective or an objective point of view. ${ }^{11}$ Many countries, including the United States and Germany, ${ }^{12}$ require subjective newness in the sense that the invention must be new to the inventor himself; the applicant for patent must be the inventor or must have acquired the right to patent from or on behalf of the inventor. In addition, most states require some degree of objective newness, meaning simply that the invention must contribute something to the common fund of information which was not there before.

The necessity of objective newness thus expresses two requirements. First, the invention must be a contribution having "inventive level"; this simply means that it must not be obvious from the state of the prior art. ${ }^{13}$ The second requirement of objective newness is that the

${ }^{8}$ E.g., Freedman v. Overseas Scientific Corp., 248 F.2d 274 (2d Cir. 1957), where plaintiff sued for infringement of his patent on magnetic false teeth. To the objection of the defendant that the invention lacked utility, the court replied, at 276 , that "An article may have patentable utility even though the patented device is not unfailingly operable in all its applications." It is clear that even a small degree of utility will support a patent; In re Holmes, 63 F.2d 642, 643 (CCPA (Patents) 1933); In re Oberweger, II 5 F.2d 826, 828 (CCPA (Patents) 1940); and even an improvement in simplicity of construction shows utility; Monogram Mfg. Co. v. Glemby Co., 136 F.2d 96I, 962 (2d Cir. I943).

${ }^{10}$ The basic test of utility is commercial practicability. TouLM1N, op. cit. supra note 4 , at 49. This sort of of test is expressly recognized in the German statute, which requires an invention to "permit industrial exploitation." PatG para. 1; consult appendix. The American courts also require the use to be beneficial-that is, that the invention be capable of beneficial use. The requirement is not strictly applied, however, as Canadian-American Pharmaceutical Co. v. Coe, I26 F.2d 847 (D.C. Cir. I942), clearly demonstrates. There, a patent medicine for cancer was shown to do no harm and to help in relieving pain from cancer, although experiments on animals showed no effect on the cancer itself. The court, nevertheless, held the medicine to have patentable utility.

Ix This is the approach of Elster, GewERblicher Rechtsschutz I54 (I92 I).

${ }_{35} 3$ U.S.C. $\S 102$ (f) (1952); PatG para. 3, 4; consult appendix. Note that under PatG para. $4(3)$, a person other than the inventor can secure issuance of the patent, even on the basis of the inventor's work, unless the inventor objects. But under PatG para. 3 , the right to the patent belongs to the inventor, and he is, therefore, given an action against an unauthorized applicant for assignment of the application (or for transfer of the patent, if it has been issued); PatG para. 5. See also Dimet Proprietary, Itd. v. Industrial Metal Protectives, Inc, log F. Supp. 472, 478, 479 (D. Del. I952).

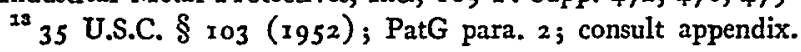


contribution must not already have been made. The distinction between this requirement and that of inventive level seems dubious at first glance, since anything which has already been contributed to the particular art involved would seem to be obvious from the state of the prior art. The validity of the distinction lies in the difference between "if" and "when." The requirement of inventive level asks "if" the inventive idea is obvious from the prior art. The second requirement asks "when" contributions of the inventive idea become part of the prior art so as to exclude a later contribution of the same idea from achieving the status of inventive level. The latter requirement is tested in the patent laws of various countries by specific statutory time limits, and it may thus be designated as the requirement of "statutory novelty."14

The general notion of newness in the phrase "new and useful" thus contains three elements: (I) invention by the applicant or his legal predecessor, (2) inventive level in relation to the prior state of art, and (3) application for patent of the idea within the statutory time limits. Whether or not the applicant is the inventor is largely a question of fact, and one which must be determined in each case. The requirement of inventive level is one of the central problem areas of substantive patent law, and it is obviously too broad a field for the present consideration. ${ }^{11}$ It may be left to one side here because it is a problem almost invariably requiring the assistance of expert patent counsel, while the present concern is mainly with problems which may concern the general practitioner. It is to the third element, therefore, that the attention of the general practitioner is especially directed. His acquaintance with the principal procedural requirements of patenting, both at home and abroad, not only may save his client unnecessary expense, but may make the difference between patentability and unpatentability itself.

Although the time limits and procedural requirements designated above as statutory novelty differ widely from country to country, their very nature suggests a further refinement of the general policy basis for patent systems. The reason for promoting inventiveness lies in the desirability of making new products and skills available to the whole community. It is true that the grant of a patent monopoly temporarily

\footnotetext{
"The term "statutory novelty" is frequently used in a broader sense to include either or both of the requirements of invention by the applicant and inventive level, as well as the requirement it is here used to designate. This practice leads to confusion, and the terms are separated here as an aid to analysis. See also note 56 infra.

${ }^{26}$ The connection of the concept of inventive level with that of statutory novelty is discussed infra under the heading of Statutory Novelty.
} 
restricts manufacture of a product or use of a process by the general public, but this is counterbalanced by the fact that the value of the patentee's monopoly depends on the extent to which he makes his finished product available to the community. On the other hand, the inventor should not be allowed to exterid his monopoly by waiting to apply for a patent until competition appears imminent. The requirements of statutory novelty are designed to force the inventor to disclose his invention and to make early application for his patent, and this result is accomplished by denying him the benefit of a patent monopoly if he delays. ${ }^{16}$

\section{B. Uniformity and Lack of Uniformity}

An examination of the appendix to this paper, which compares the American and German patent statutes, will reveal significant differences of method used to implement the common policies underlying the patent system. Germany was one of the first European countries to adopt a patent statute; many of the German states had their own patent laws, and these were replaced when a general statute applicable to the whole Reich was adopted in $1877^{17}$ Some uniformity among the other European statutes resulted from widespread copying of the original German Patentgesetz, but subsequent amendments and revisions have led to many technical variations. ${ }^{18}$ The German statute itself has undergone a number of revisions, culminating in the Patentgesetz of $1953^{19}$ (hereafter referred to as the PatG). The original United States statute adopted in 1790 has also been the subject of a number of revisions. ${ }^{20}$

\footnotetext{
${ }^{10}$ For an excellent discussion of the policy basis of patent law, as well as an analysis of the inadequacies of the American system, see Bush, Some Proposals for Improving the Patent System, 39 J. PAT. OFF. SoCy i (1957). It is, of course, sometimes possible for an inventor to maintain a monopoly over his invention indefinitely, simply by keeping its details secret. This is particularly true of processes, formulas, and the like.

${ }^{27}$ Elster, op. cit. supra note $\mathrm{I} \mathrm{I}$, at 200 .

${ }^{18} I d$. at 201, 202. Countries which originally patterned their statutes after the German patent law included Austria, Belgium, Denmark, Norway, Sweden, Italy, Switzerland, Russia, and Spain. Various organizations concerned with European integration have exerted a strong influence for uniformity since World War $\mathrm{II}_{3}$ especially important products of this influence are Euratom and the treaties adopted by members of the Council of Europe for the classification of, and application for, patents. Text of the application treaty is given in full, in English, French, and German in V. 56(2) GEWERBLICHER RECHTSSCHUTZ UND URHEBERRECHT 153-62 (1954). On ratification, See Io International ORganization 2 I9 (1956).

${ }^{19}$ PatG 18 . Juli 5953 (BGBI I 623). An excellent annotation and commentary on the present statute is Busse, Patentgesetz (2d ed. 1956).

${ }^{20}$ See Toulmin, op. cit. supra note 4 , at $23-34$, for a history of the American patent law development.
} 
The latest re-evaluation of American patent law resulted in the Patent Codification Act of $1952^{21}$ (hereafter referred to as the PCA).

One of the most important differences between the various national laws lies in the administration of patent issue, and the difference is especially significant in its relation to the treatment of statutory novelty. Generally speaking, the patent countries administer the grant of patents in three ways: ${ }^{22}$

(r) Registration. A number of countries do not require formal proof of patentability. Patents are simply granted upon application, and the test of patentability is left to the courts should a dispute later arise.

Included in this group are Belgium, France, Greece, Luxembourg, Spain, and Bolivia.

(2) Examination. The United States, ${ }^{23}$ Germany, ${ }^{24}$ Denmark, Finland, Norway, Sweden, Japan, The Netherlands, Austria, and Brazil are the principal countries which require a determination of patentability before a patent will be granted. Ordinarily, the procedure is as follows: The applicant files for a patent, asserting his claims. The patent office examines the claim and researches the prior art in its technical library in order to determine whether or not the requirement of statutory novelty is met. Great Britain and some of the Commonwealth countries have a similar system, but search is more restricted. ${ }^{25}$

(3) Publication. In order to assure the fullest possible opportunity for determining patentability, some countries require publication of patent applications, so that interested parties who fear interference with their own patents or applications for patent may object to the issue of

${ }^{21} 35$ U.S.C. $\$ \S$ r-293 (1952).

${ }^{22}$ This classification is principally borrowed from BUSSE, op. cit. supra note 19, at 8 ; cf. SCHER, op. cit. supra note 6 , at $58-60$. The countries falling in the various categories are those cited by Busse, and the caution should be advanced that Scher disagrees in several instances.

2335 U.S.C. $\$ 13 \times(1952)$.

${ }^{24}$ PatG, para. 28. Before 1943 , examination was required in Germany and normally given. Between 1943 and May 8, 1945, examination was legally normal, but in practice only summary. From 1945 until January 1,1952 , no examination at all was made. Since 1952, however, examination has been thorough. Classen, Some Aspects of German Patent Law and Procedure, 38 J. PAT. OFF. Soc'y 793, 795 (1956).

${ }^{25}$ Search for prior art references was formerly limited in Great Britain to domestic patents. Busse, op. cit. supra note 19 , at 8 . The English statute has been amended, however, to include search of publications, both domestic and foreign, but only as to those which constitute knowledge in Britain, apparently meaning that copies must exist in Britain at the relevant time. Johnston, The Criterion of Novelty Under the British Law-Principal Differences Between Countries on the Question of What Prior Publication or Use Invalidates a Patent, $40 \mathrm{~J}$. Pat. OFf. Soc'Y ${ }_{4} 4$ (1958). 
a patent. This adninistrative device is not exclusive of the registration and examination classification, but cuts across the other two classes. Thus, Germany and the United States both require examination, but Germany also requires publication. ${ }^{26}$ The United States not only does not require publication, but, on the contrary, provides specifically by statute that patent applications are to be held in confidence by the Patent Office. ${ }^{27}$ Other countries which require publication are Denmark, Finland, Japan, The Netherlands, Norway, Austria, Sweden, and Brazil. ${ }^{2 s}$

Another variation with which the international lawyer should be familiar is the difference in the degree of finality which may be attached to the grant of a patent. Lawyers trained in the common law have gradually become accustomed to the notion that all administrative decisions are not subject to judicial review. Where judicial review is provided, however, it would be unthinkable to such lawyers that review should not extend to the validity of the administrative action. Thus, in the PCA, it is specifically provided that invalidity of plaintiff's patent is a defense in an infringement suit. ${ }^{29}$ In striking contrast is the situation in Germany, where the validity of a patent is conclusive upon the courts in an infringement suit. Validity of German patents, once granted, can only be attacked by a proceeding initiated with the Patent Office. ${ }^{30}$ It should be noted that this conclusive presumption of validity is not applied in those civil law countries which have adopted the registration system, since patentability is left to the courts under that method of administration.

A substantial majority of the important nations of Europe and Latin

${ }^{20}$ The application is published once in the Patent Office Gazette and is publicly displayed at the Patent Office. PatG para. 30. As publication in the Gazbtte gives only the applicant's name and the title of his invention, only a modicum of protection is offered by that method. Since 1955 , the Patent Office has also issued the complete application in printed form. Busse, Procedure and Practice in the German Patent Office, 38 J. PAT. OFF. SOC'Y 683,687,688 (1956). Within three months after publication, any person may file an objection in writing, giving his grounds for nonissue of the patent. PatG para. 32. See also Rosa, German Printed Applications, 39 J. PAT. OFF. Soc'Y 534 (1957).

${ }^{27} 35$ U.S.C. $\$ 122$ (1952). A discussion of secrecy and the problems of protecting nonpatented or nonpatentable inventions appears in Bush, Some Proposals for Improving the Patent Systenn, 39 J. PAT. Off. Soc'Y I I, esp. 21-24 (1957).

s9 Busse, Patentgesetz 8 (1956).

${ }^{20} 35$ U.S.C. $\$ 282$ ( 1952 ).

${ }^{30}$ PatG para. 13, 17, 37; Busse, Procedure and Practice in the German Patent Office, 38 J. PAT. OfF. Soc'y 683 (1956). 
America have statutory provisions covering the nonuse of a patent by the patentee. $^{31}$ These provisions are usually referred to as "compulsory license" provisions, but in fact they often go beyond this remedy and provide for complete forfeiture or withdrawal of the patent under certain circumstances. The German PatG, for example, provides that if the patentee refuses to allow the use of the invention to another person who offers to pay reasonable compensation, then the person desiring to use the invention may obtain authority to use it from the Patent Office in any case where such use is in the public interest and where at least three years have elapsed since issue of the patent was made public. ${ }^{32}$ The statute also provides, however, that the patent is to be withdrawn if the invention is exclusively or mainly exported outside Germany. Such withdrawal can be demanded by a potential user only after two years from the grant of a compulsory license, and only if the public interest cannot be satisfied in the future by the granting of further compulsory licenses. ${ }^{33}$ Compulsory license provisions have been suggested in the United States, but no such requirement has ever been adopted here. ${ }^{84}$ The foreign provisions are important for the American inventor who contemplates patenting abroad solely for the purpose of aequiring a "paper patent," which he could use to protect markets or to prevent competition at the place of production without marketing in the country of production. ${ }^{35}$

The United States' requirement of a license to export inventions has

${ }^{31}$ Graham, Footnotes on Foreign Patent Practice, 39 J. Par. OFf. Soc'y 623, 634 (1957).
${ }^{32}$ PatG para. $15(1)$.
${ }^{33} I d$. para. $15(2)$.

${ }^{34}$ Castel, Recent Trends in Compulsory Licensing in Case of Non-use of Patents: A Comparative Analysis, $36 \mathrm{~J}$. PAT. OFF. Soc'Y 330 (1954). Although not as far-reaching in its effects as the compulsory license provisions, the adoption by the American courts of the so-called "paper-patent doctrine" is a long step in the same direction. Under this rule the patentee who fails to develop the subject of his patent is given the narrowest possible range of equivalents as a penalty for his nonuse (or perhaps more accurately, to prevent him from impeding progress). Such a patentee is not likely to succeed in an infringement suit unless the defendant's infringement falls squarely within the scope of the patent. See, e.g., Glendenning v. Mack, 159 F. Supp. 665, 668, 669 (D. Minn. 1958). Compulsory licensing may occur in the United States as a result of misuse of a patent as opposed to nonuse. E.g., United States v. National Lead Co., 332 U.S. 319 (1947). But the significance of this remedy lies in antitrust law, and the important areas where patent law and antitrust law meet are too broad for consideration in the present paper.

${ }^{35}$ In some countries, it is possible to keep a paper patent alive by offering the patent for license. ScHER, op. cit. supra note 6 , at 62 . Scher refers to treaties between the United States, Germany, and Switzerland, by which domestic working by a patentee will 
already been noted. ${ }^{36}$ In essence, the rule to be observed can be stated as follows: A license from the Commissioner of Patents is required before any application for a foreign patent is filed upon an invention made in the United States, where such foreign application precedes, or follows within six months, the filing of an application in the United States. ${ }^{37}$ As noted above, violation of this requirement may result in severe penalties, including criminal liability as well as unpatentability of the invention. The Commissioner is authorized to grant retroactive licenses where the foreign filing occurred through inadvertance, but he is not allowed to do so if the invention is found to relate to the national security. ${ }^{38}$ No cognate requirement of licensing appears to exist in German patent law, although there are important provisions relating to inventions of concern to national security..$^{39}$ The lawyer should be alert, however, to the possible existence of such provisions in other foreign systems, particularly when he is advising an American firm which draws on its foreign branches or subsidiaries for new ideas and processes.

II

\section{Treaty Provisions}

\section{A. The Paris Convention for the Protection of Industrial Property}

Most of the important trading countries of the world, aside from the Soviet Republics and Red China, have adhered to the Paris Convention of 1883 , or, as it is frequently called, the Union. The Convention has undergone a number of revisions since its conception, the latest being that of Lisbon in the fall of $1958 .^{40}$ This revision has not

protect his foreign patent right, but no citation is given and the text has not been found. See, in general, Castel, supra note 34 , at $330-40$.

${ }^{30}$ See note I supra.

${ }^{37}$ It is not completely clear from the wording of the statute that a license is required where foreign filing precedes the filing in the United States; 35 U.S.C. $\$$ I $\$ 4$ (1952); consult appendix; but the reasons for the existence of the section obviously require licensing both before and within six months after domestic filing. This is the interpretation placed on the section by the Commissioner; 37 C.F.R. 5.1 (1953).

35 U.S.C. $\$ \$ 181,184(1952)$. 20 PatG para. $30 a$.

so Results of the Lisbon Conference have not yet been available to the writer in English, but have been published in French by the Bureau Internationale pour la Protection de la Propriete Industrielle (Textes adoptés par la Conférence diplomatique de Lisbonne le 31 octobre 1958). The revision was signed by representatives of $3 \mathrm{I}$ nations, including both the United States and Germany, and it remains open for further signatures. The revision does not alter the patent provisions of the treaty in any startling way, but some of the interesting changes have been summarized by notes in the appendix hereto. A general rearrangement of the text proposed by the International Bureau (which serves as the Secretariat for the Union) was not adopted. See 2 INTrRnationaI 
as yet been ratified, and in the meantime, the next earlier revision, that of London in 1934, remains effective. ${ }^{41}$ Both the United States and Germany are members, and the London revision became effective as to both of them in $1938 .{ }^{42}$

Although the Convention deals with a number of topics, the provisions of chief importance relate to reciprocal observance of priority in the filing of patent applications. ${ }^{43}$ If a national or corporation of one member of the Union files a patent application in one of the member states, and within one year thereafter files an application in another member state, then the latter state is bound to give his (second) application the same priority under its own internal law as the same application would have had in that state if filed on the date of the first application. The rights of the state of second filing to deny a patent because of events which preceded the first filing are not affected. ${ }^{44}$ A concrete example will clarify these rules.

Suppose that $A$, an American, files his application in the United

Bureau of the Industrial Union, Lisbon Conference Preliminary Documents (1957). Unlike the London Revision, which did not go into effect for many countries until four years after the conference, the Lisbon Revision is expected to be in effect by June 1959 , and ratification before that date was urged at Lisbon. GEWERBLICHER REChTSSCHUTZ UND URHEBeRRECHT (AUSLANDS UND INTERNATIONALER TEIL) Nr. 12 s. 553 (1958).

${ }_{41}$ Text of the London agreement appears in 53 Stat: 1748 (English version at 1772) (1934). A history of the Paris Convention is given in Briskin, Foreign Priority Rights under Section $x 19$ of the Patent Act of $195^{2-T}$ The New Prerequisite as to Time of Filing Copy of Foreign Application, 39 J. PAT. OFF. Soc'x 94, 99-108 (1957).

${ }^{42} A$ list of member countries as of January 1,1958 , and the dates when the London Revision became effective as to each is given in GEWERBLICHER RECHTSSCHUTZ UND URHEBERRECHT (AUSLANDS UND INTERNATIONALER TEIL) 28 (1958).

${ }^{43}$ Art. 4 of the Paris Convention; see note $4 \mathrm{I}$ supra. The American and German provisions implementing these rules are 35 U.S.C. $\S \S$ 104, I19 (1952); PatG para. 7, 27 ; consult appendix.

${ }^{4}$ Art. ${ }_{4} \mathrm{~B}$ of the Paris Treaty; see note $4 \mathrm{I}$ supra. One interesting aspect of the American statute is that the provisions barring patentability one year after public use in the United States or after publication expressiy state that such use or publication one year prior to the actual date of filing in the United States shall be a bar. The Convention reserves the right to members to legislate as to events affecting patentability if couched in terms of legislation on "rights acquired by third parties before the day of the first application on which priority is based. ..." Art. $4 \mathrm{~B}$. It would seem, therefore, that Congress has violated the provisions of the Convention by making the one-year period overlap the priority period; "rights of third parties" would certainly seem to include rights of the general public to use the invention which has become unpatentable. - The Convention provisions have not been regarded as self-executing in the United States. Thus, when the Convention gave treaty priority to design patents filed in member countries within six months after a foreign filing, but at a time when the American statute 
States on January I of any given year. Later in the same year, $A$ files an application for patent on the same invention in Germany. The German Patent Office is then bound to give his German application the same priority it would have had, had the same application been filed with the German Patent Office on January I. ${ }^{45}$ No claim by an intervening applicant and no publication or public use during the interval between the two filing dates can be allowed to defeat the priority of $A$. Since another person's publication of an inventive idea before the filing of an application bars issue of a patent under German law, ${ }^{46} A$ 's invention may still be unpatentable in Germany if such publication occurred before January I-that is, before $A$ 's treaty priority date.

The treaty priority provisions are clearly of great importance and usefulness. In the absence of such a convention, it would be necessary for an applicant who contemplated patenting in several countries to file his applications simultaneously in all of them. If he failed to do so, it might be possible for other persons to steal his invention by filing in the foreign country before the actual inventor did so. Unfortunately, however, there are weaknesses in the treaty priority system with which the international lawyer should be familiar. A consideration of these weaknesses will follow under the heading of Problems.

\section{B. United States-German Treaty of Friendship, Commerce, and Navigation}

The treaty of friendship, commerce, and navigation negotiated between the United States and the Federal Republic of Germany in I954 was ratified by both countries and went into effect between them on July I4, I956. ${ }^{47}$ Like the other treaties of similar nature which the United States has entered into since World War II, it contains many provisions of importance to the international lawyer. Its most important contribution to the field of patent law is the undertaking by each party to afford "national" treatment to nationals and companies of the other party in the acquisition of patents and other types of industrial property. ${ }^{48}$ National treatment is defined as treatment by each party,

gave such priority only to applications filed within four months of the foreign filing, treaty priority was refused to a filing by a French citizen who conformed with the treaty but not with the statute. 2 HackWORTH, Digest of INTERnational LaW 42 (1941). In Germany, treaties take precedence over statutes and are self-executing as well by virtue of a constitutional provision. GRUNDGESETZ FUER DIE BUNDESREPUBLIK DeUtschland vom 23. Mai 1949 (BGBl 2) Art. 25.

${ }^{45}$ PatG para. $7(3)$; consult appendix.

${ }^{47}$ Text and accompanying documents at TIAS 3593 .

${ }^{10} I d$. para. 2.

${ }^{48} I d$. art. $\mathrm{X}(\mathrm{I})$. 
in its territories, of persons belonging to the other party, "upon terms no less favorable than the treatment accorded in like situations to nationals, companies, products, vessels and other objects" of its own..$^{40}$ Arbitration of any dispute which cannot be settled by negotiation is provided for, as well as referral by agreement to the International Court of Justice. ${ }^{50}$

\section{III}

\section{Statutory Novelty}

\section{A. In the United States}

Even assuming that the applicant or his legal predecessor invented the subject matter of a patent application, and even though that subject matter would otherwise qualify under the requirement of inventive level, the issue of a patent in the United States is, nevertheless, barred by section 102 of the PCA if the applicant has abandoned the invention, if the invention has been anticipated, or if the applicant delays in filing his application for patent. ${ }^{51}$

\section{Abandonment}

As one might expect, an express, voluntary abandonment of an invention may but rarely does occur. An intention to abandon may be inferred from delay, and it is, therefore, apparent that the inventor faces a day-by-day risk of abandonment after his conception and until reduction to practice.52 An abandonment may also be found to result from inaction after application, if the applicant fails to take any further steps necessary to perfect his patent claim. ${ }^{53}$

There are two other situations in which rules closely akin to the doctrine of abandonment may bar patentability. One is the case where the invention is found to relate to national security, and the inventor later makes an unauthorized use of the invention. The right to patent is forfeited, and this loss has sometimes been referred to as "involuntary" abandonment. ${ }^{54}$ In reality, the forfeiture is nothing more nor less than

\footnotetext{
${ }^{10}$ Id. art. XXV. ${ }^{60}$ Id. art. XXVII.

"Consult appendix. The classification used here is a modification of that given by Woodling, Inventions and Their Protection 182, 183 (1954).

${ }^{52}$ Electric Battery Co. v. Shimadzu, 307 U.S. 5 (1939); Toulmin, op. cit. supra note 4 , at 147 ; Woodling, op. cit. supra note $5 \mathrm{I}$, at 184 .

${ }^{53}$ Abandonment in this case is of the application, not of the invention. It is governed by the PCA and Rules of Practice of the Patent Office, and ordinarily occurs after six months failure to prosecute the claim. Revivals are allowed in appropriate cases. 35

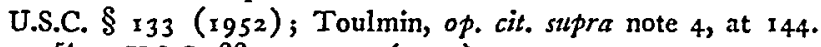

54 U.S.C. $\$ \S$ I8I, 182 (1952).
} 
an exercise of the power of eminent domain. The other situation involves a "relative" sort of abandonment, and it arises in interference proceedings between inventors who have conceived the invention independently of one another. If, for example, inventor $A$ conceives the invention first but fails to reduce the inventive idea to practice within a reasonable time, he may find that his subsequent application for patent is barred in favor of an application by inventor $B$, who conceived the invention later but who acted more promptly. ${ }^{55}$ Under section $102(\mathrm{~g})$ of the PCA, $A$ would have a presumptive right to the patent, but his priority may be lost by a failure to exercise reasonable diligence in reduction to practice.

\section{Anticipation ${ }^{56}$}

In the broad sense, anticipation means simply that the inventive idea has become part of the prior art before conception of the idea by an applicant. Anticipation may consist of either unpublished or published knowledge.

a. Unpublished knowledge. As noted above, in the United States, priority of conception and reduction to practice give priority of right to patent. This priority exists even if the prior inventor is not the first applicant or the first patentee, and even if his invention has not been made public. ${ }^{57}$ Patentability of the inventive idea as such is not affected, but only the eligibility of one applicant as opposed to another.

${ }^{5}$ Woodling, op. cit. supra note $5 \mathrm{x}$, at 184,185 .

${ }^{50}$ There is some measure of confusion in the articles, cases, and texts on patent law with respect to terminology. "Anticipation" seems sometimes to be used to include both the provisions treated here and the delay provisions as well. Granting that delay in application is anticipation in the sense that the subject matter may thereby become part of the prior art, still it seems worthwhile to distinguish these categories. When the term is used broadly, it is possible to say that an inventor has anticipated himself if his own public use or publication precedes his filing by more than one year. It seems more sensible to say that he has lost his right by delay. Moreover, several features distinguish the anticipation from the delay provisions. First, all anticipation provisions are concerned only with patentability by the applicant in question, in relation to other persons who have either a better or poorer right to the patent. Delay provisions relate, on the other hand, to the patentability of the subject matter itself, by anyone. Second, anticipation is significant in American law only with respect to the conception date, while delay provisions are concerned with the filing date. The latter distinction is especially important in a comparative study such as this, because almost all foreign systems, including Germany, govern the right to patent solely by priority of application. PatG para. 3 ; consult appendix. Since conception date is, therefore, irrelevant in most foreign systems, the statutory novelty provisions of the foreign statutes equate only with the delay provisions in the PCA. See also note 14 supra.

${ }^{57} 35$ U.S.C. $\S_{102}(\mathrm{~g})$ (1952); consult appendix. 
In like fashion, public use of the inventive idea in the United States before conception, whether or not such use is based on the inventive conception of another applicant, bars issue of a patent to the later inventor. ${ }^{58}$ Public knowledge or use alone which occurs outside the United States does not bar issue of a patent to a person who later conceives the idea and files in the United States. ${ }^{59}$ Here, too, the patentability of the subject matter itself is not affected; the bar applies only to persons whose date of conception is later than the domestic public use.

b. Published knowledge. An applicant may not be issued a United States patent if his inventive idea has been described in a patent or a printed publication anyzohere in the world, if such description occurred prior to his conception of the idea. ${ }^{60}$ As in the case of unpublished knowledge, only the right of individual applicants is affected, and not patentability itself. In addition, section IO2 of the PCA proscribes issue of a patent to an applicant whose invention has been described in a patent issued by the United States and which was issued on an application filed before the conception date of the later applicant. ${ }^{01}$ It has already been noted that applications for patent in the United States are not published, but, on the contrary, are required to be held in confidence by the officials of the Patent Office. ${ }^{62}$ Under this rule, however, the filing of an application is made equivalent to publication, so as to bar any later applicant whose conception date was after the filing of the original application.

\section{Delay}

Unlike the bar of anticipation, delay affects not the priority of applicants, but the patentability of the invented subject matter by anyone. The conception date of the individual applicant is irrelevant to the determination of delay; the significant date in this connection is the date of filing of the application in the United States. The statutory bar of delay operates in three situations:

a. Issue of a United States patent is barred if the inventive idea has been shown or described in a patent or publication anywhere in the

${ }^{\text {EB } I d . ~ a t ~} \S \mathrm{OO2}(\mathrm{a})$. It will be noted that the statute says "known or used" by others in this country. (Emphasis added.) The courts have interpreted this to mean "known and used." Stearns v. Tinker and Rasor, 220 F.2d 49, 56 (9th Cir. 2955), cert. denied, 350 U.S. 830 (1955).

${ }^{60}$ Dimet Proprietary, Ltd. v. Industrial Metal Protectives, Inc., xog F. Supp. 472, 478 (D. Del. r952).

${ }^{\circ 0} 35$ U.S.C. § 102(a) (1952); consult appendix.

0235 U.S.C. \& $102(e)(1952)$.

${ }^{02}$ See text at note 27 supra. 
world more than one year prior to filing of the application in the United States. ${ }^{33}$ It should be noted that this (as well as the other statutory bars of delay) operates in addition to the bar of anticipation, and either bar may operate without the other. ${ }^{64}$ Suppose that $A$ invents $X$, and the idea of $X$ is later published. $A$ 's subsequent application for patent is not affected by anticipation because his conception date preceded publication. The idea $X$ may, nevertheless, become unpatentable in the United States if neither $A$ nor another inventor files an application for patent within one year of the publication. It should be noted that the statute makes no distinction as to the persons responsible for publication; thus, $A$ may lose his right to a patent because of his own publication, if he fails to file within one year after the publication takes place.

b. Issue of a United States patent is barred if the subject matter has been in use or on sale in the United States for more than one year prior to the filing of an application in the United States. ${ }^{65}$ Just as in the case of delay after publication, this bar is independent of the question of anticipation, and the statute makes no distinction as to persons. Thus, if $A$ invents $X$ and subsequently produces and sells a product incorporating $X$, he may not be issued a patent unless he files within one year of the date when $X$ was used or on sale in the United States.

c. Issue of a United States patent is barred if the inventor has filed for a foreign patent on the same invention more than twelve months before filing in the United States, unless the United States patent issues before the foreign patent. ${ }^{66}$ The implications of this provision are obvious, but its relation to the treaty priority provisions of the Convention for the Protection of Industrial Property should be noted. Thus, if $A$ invents $X$ and files an application for patent of $X$ in Germany, an application filed in the United States within one year after the German filing will be given priority as if it had been filed at the same time as the German application. If $A$ fails to file until more than one year after the German filing, he will not only lose his treaty priority, but he also runs the risk of unpatentability in the United States. His only method of avoiding unpatentability in the United States after the year has expired is to delay the issue of the foreign patent until the United States patent has been applied for and issued. Since the issue of a

\footnotetext{
${ }^{63} 35$ U.S.C. $\S$ I02(b) (1952); Osborn Mfg. Co. v. Newark Brush Co., III F. Supp. $846,849,850,85$ I (D.N.J. 1953).

"Note that all of the subparagraphs of PCA 102 are joined disjunctively by "or." Consult appendix.

${ }^{05}$ Note 63 stpra. $\quad{ }_{35}^{86}$ U.S.C. $§ 102$ (d) (1952); consult appendix.
} 
United States patent is an extremely time-consuming process, such delay may also injure his rights under the foreign application. ${ }^{67}$

\section{B. In Germany}

The requirements of the German Pat $G$ are much simpler than those of the PCA in the United States. Priority of right to a patent between two or more inventors who have conceived the idea of the invention independently depends entirely upon priority of filing. ${ }^{68}$ The only statutory provisions on abandonment relate to abandonment of the patent, not of the invention. ${ }^{99}$ The other requirements may be summarized as follows: An invention is not regarded as new if:

(I) the inventive idea has been publicly used in Germany prior to his filing of an application for patent; or

(2) the inventive idea has been published anyrohere in a publication originating within the last one hundred years before the filing of an application for patent; unless

(3) such use or publication occurred within six months preceding the filing and rested on invention by the applicant. ${ }^{70}$

Although there is an obvious similarity between these requirements and those of the United States, these rules do not equate precisely with the bars of either anticipation or delay in the PCA. In keeping with the terminology employed in the preceding discussion of the American statute, these German rules must be classified as purely "delay" provisions, because the date of filing is the only significant date. The date of conception is irrelevant. Unlike the one-year grace period between publication or use and filing provided for in the PCA, the PatG gives a grace period of only six months, and even this shorter grace period is granted only when the publication or use is based on the conception of the applicant.

Whatever terminological classification may be applied to either the American or German provisions, the basic ingredients of prior public use and publication as bars are the same. Moreover, in both countries, only domestic use is a bar, and both adhere to the rule that any domestic or foreign publication is a bar. It is important to note, however, that there

${ }^{67}$ Current estimatees place the average time interval between application and issuc of a United States patent at about $3^{1 / 2}$ years. Briskin, Foreign Priority Rights under Section 119 of the Patent Act of 1952-The New Prerequisite as to Time of Filing Copy of Foreign Application, 39 J. PAT. OFF. Soc'Y 94, 107 (1957) (citing the Official Gazette).

${ }_{70}^{68}$ PatG para. 3; consult appendix. ${ }^{69}$ Id. para. 12.

${ }^{70} I d$. para. 2 (all three requirements). 
may be significant differences in the meaning assigned to the words "use" and "publication."

It will be recalled that at the outset of this discussion a distinction was made in the concept of objective newness between the requirement of inventive level and what has here been discussed under the heading of statutory novelty. ${ }^{71}$ It was suggested that inventive level refers to the conception of an idea which rises above the state of the prior art; it asks the question "if" an inventive idea is an advance or only part of the prior art. Statutory novelty requirements, on the other hand, ask the question "when" inventive ideas have become part of the prior art so as to prevent subsequent conception of the same idea from attaining inventive level. It is apparent that there is a connection between these two questions; if, in answering the question "when," one must conclude that the idea has become part of the prior art, then one must also conclude that subsequent conception of the same idea does not have inventive level. This connection is made explicit in the German statute, which expressly conditions the application of the statutory bar on 'whether or not the use or publication has been such that "use by other persons skilled in the art appears possible thereafter."72 Thus, it is apparent that the use or publication contemplated by the Pat $G$ need not be of exactly or even substantially the identical invention as that of the applicant; so long as other persons knowledgeable in the art would see an obvious application of the published or used idea to the subject matter of the application, issue of a German patent on that application is barred.

The PCA, on the other hand, attempts to make inventive level and statutory novelty two separate and distinct requirements. Thus, section IO3 states that ${ }^{73}$

A patent may not be obtained though the invention is not identically disclosed or described as set forth in section ro2 of this title, if the difference between the subject matter sought to be patented and the prior art are such that the subject matter as a whole would have been obvious at the time of the invention to a person having ordinary skill in the art to which said subject matter pertains. (Emphasis added.)

${ }^{71}$ See text at notes 13,14 supra.

${ }^{72}$ PatG para. 2. Note the diffculty of translation of the word Sachverstaendige in the German provision; see appendix in discussion opposite PCA § 103, and Classen, sulpra note 24 , at 801 .

${ }_{33} 35$ U.S.C. $\& 103$ (1952); consult appendix. 
Thus, the use or publication contemplated in the PCA provisions on statutory novelty must be at least substantially identical to the subject matter of the applicant's invention before issue of a patent to him will be denied on that ground. It is submitted that this difference between the American and German statutes is more formal than real, and that it demonstrates a lack of clear analysis by the draftsmen of the American statute. Section 103 attempts to distinguish between prior use and publication, on the one hand, and the prior art on the other. It is difficult if not impossible to conceive of the prior art, from which an advance was obvious, as consisting of anything except prior use or prior publication or both. If the wording of the PCA adds anything, it is a contribution to confusion; prior use is clearly included in the "prior art," but we are not told whether only domestic use is involved or whether use in foreign prior art is also included.

Even in the face of the foregoing formalistic difference, the concept of prior use has received highly similar construction in the two legal systems. More than an experimental use is required. ${ }^{74}$ The use must be public in the sense that it is not intentionally secret, but it need not be exposed to the public view. ${ }^{75}$ Thus, the use of a part in an automobile engine would constitute a public use, although its location in the mechanism would prevent it from being seen by the public at large. ${ }^{76} \mathrm{~A}$ single instance of use is sufficient to raise the bar. ${ }^{77}$

The situation with respect to publication is more complex. Both systems require "printed publications," although it seems clear at least under German law that multiple reproduction by a chemical process is also included in the definition. ${ }^{78}$ In both systems, periodicals and books of all kinds are, of course, included, without regard to the size of circulation, so long as the matter is available to the public. ${ }^{70}$ Foreign patents

\footnotetext{
${ }^{74}$ Electric Battery Co. v. Shimadzu, 307 U.S. 5 (1939); Application of Schlittler, 234 F.2d 882 (CCPA (Patents) 1956); Busse, PatentGesetz i I (1956) (citing NA RPA in Bl. 1916 s. 75).

${ }^{76}$ WOOdLing, op. cit. supra note 51 , at 188 ; Busse, PATENTGESETZ 114 (1956) (citing BA RPA in Bl. 1906 s. 213).

${ }^{76}$ Woodling, op. cit. stipra note $5 \mathrm{I}$, at 188 ; Busse, Patentgesetz 116 (1956).

${ }^{77}$ Woodling, op. cit. supra note 5I, at I89; Busse, PATENTGESETZ II4 (1956).

${ }^{78}$ Busse, PATENTGesetz i04 (I956). Apparently, at least microfilm reproductions are not "printed" publications in American law. In re Tenney, Frank and Knox, ${ }_{117}$ USPQ 348 (1958), cited and discussed in Mediger, Was Gilt in USA als Druckschrift, GEWERBLICHER RECHTSSCHUTZ UND URHEBERRECHT (AUSLANDS UND INTERNationaler TeiL) Nr. 12 (Dez. 1958) at 569.

${ }^{79}$ Busse, PatenTGESETZ 108, ro9 (1956); Woodling, op. cit. supra note 51 , at 192.
} 
are also included. ${ }^{\text {so }}$ There is some controversy in the United States as to whether typewritten masters' and doctors' theses are included; ${ }^{\text {s1 }}$ in Germany, it is probable that such documents are included, at least if they are on file in German libraries. ${ }^{82}$

One fo the main differences between the two systems arises from the German doctrine of die allgemeine Erfindungsgedanke, which translates roughly as "the general inventive idea." In sharp contrast to the American patent system, where a patentee is protected from competition only within the specific limits of his patent claims, ${ }^{83}$ protection of the German patentee may extend beyond his patent claims, to include not only what he did claim, but also what he might have claimed. ${ }^{84}$ It has already been noted that the validity of a patent is conclusive upon the German courts. ${ }^{85}$ Thus, in an infringement suit, the court is not entitled to declare a patent invalid, but is only empowered to determine the scope of protection which will be given to the patent. In other words the conclusiveness of the patent extends to the specific limits of the patent claim, and the court may not refuse to protect the patent to this extent. But the court may give additional protection to a patent, in its discretion, where the alleged infringer has used the general in-

${ }^{80} 35$ U.S.C. $\S$ x02 (a) and (b) (1952); PatG para. 4; consult appendix.

${ }^{31}$ Coulter, Typewritten Library Manuscripts Are Not "Printed Publications," $36 \mathrm{~J}$. PAT. OFF. SOC'Y 258 (1954) (citing cases).

${ }^{82}$ Busse, PatentGeseTZ 104 (1956) (citing BA RPA in Bl. 1934 s. 215). Cf. Carter Products v. Colgate Palmolive Co., 130 F. Supp. 557, 565 (1955), aff'd, 230 F.2d 855 (D. Md. 1955), cert. denied, 352 U.S. 843 , rehearing denied, 352 U.S. 913.

${ }^{83}$ Helene Curtis Industries v. Sales Affiliates, 233 F.2d 148 (2d Cir. 1956), motion denied, $x_{3}$ I F. Supp. 119 (S.D.N.Y. 1955), cert. denied, 352 U.S. 879. At 154 , the court pointed out that “. . . a patentee may so state his claims, which will measure the scope of his monopoly, as to include only a portion of his disclosed invention and abandon the remainder to the public."

${ }^{84}$ Crotti, The Allgemeine Erfindungsgedanke in the German Patent, 39 J. PAT. OFF. Soc'y 477,479 (1957). It is arguable that this statement is too broad, and that the doctrine should be understood as only a difference in the strictness of interpretation of patent claims. German law generally views interpretation as a search for the intended meaning, and the interpreter is not restricted to the literal meaning, BuERGERLICHES GESETZBUCH para. I 33 (1900). On the other hand, it may be argued that such liberal interpretation in the case of patent claims lends itself readily to the result that protection will be given to aspects of the invention which were not actually intended by the applicant when he obtained his patent. The language of the leading German case is instructive on this point: "The patent claim has, in the first place, the aim of describing for the technician as exactly as possible the object of the invention, not, however, of exactly limiting from all sides the scope of the patent protection resulting therefrom. In this connection, many things must be reserved to later interpretation." ENTSCHEIDUNGEN DES REICHSGERICHTS (ZivilsacheN) 80, 54, 57 (1910).

${ }^{85}$ See note 30 stipra. 
ventive idea of the patentee, even though he has not infringed upon the specific claims allowed in the patent. Whether or not this discretionary protection will be given depends upon the state of the existing art; if the art is "crowded," the tendency will be to restrict the patentee to his specific claims. ${ }^{86}$

Die allgemeine Erfindungsgedanke is obviously of primary importance in actions to enforce the patent monopoly. The concern here, however, is with the effect of the doctrine on the issue of patents by the German Patent Office. That effect is by no means clear and settled. The German writers concern themselves principally with the application of the doctrine to paragraph four of the PatG, which provides that a patent will not be issued where the invention is the "subject" (Gegenstand) of a patent issued on an earlier application. ${ }^{87}$ The doctrine will probably be applied by the German Patent Office under paragraph four, but it is doubtful that it will be applied to enlarge the scope of the bar of publication under paragraph two of the PatG. At any rate, the doctrine has led to confusion in the issue of patents by the Patent Office. ${ }^{88}$ For the present purposes, it is sufficient to note the problem, without giving the arguments for or against the application of the doctrine to other publications. ${ }^{89}$

\footnotetext{
${ }^{88}$ Crotti, supra note 84 , at 490 .

${ }^{87}$ Busse, PatentgeseTz 139-41 (1956); Aders, Die Auslegung von Patenten in Deutschland, Gewerblicher RechtsschUTZ UND URHeBERRECHT (II) (1954) s. I 98 ff.

${ }^{88}$ Crotti, supra note 84 , at 500; cf. Classen, supra note 24 , at $800-14$.

${ }^{80}$ The problem, of course, arises in the courts of other countries as well as in Germany. The American courts, faced with deciding whether an invention is already part of the prior art, have looked upon the descriptions in foreign patents as limited to their express scope. Thus see Pattinson v. Watson, 148 F. Supp. 951 (D.D.C. 1957), where plaintiff brought suit on a claim for re-issue of an application denied by the Commissioner. Plaintiff's idea was to store fluids, not affected by salt, underground, by dissolving salt beds with water, extracting the saline solution, and injecting the fluid to be stored. One of the prior references relied upon by the Commissioner in rejecting the original application was a German patent which described storage of such fluids in a mechanically-mined salt mine. In holding the German patent not a valid prior reference, the court said, at 952, "In considering the German patent, the court should follow the well settled principle that 'a foreign patent is to be measured as anticipatory, not by what might have been made of it, but by what is clearly and definitely expressed in it. An American patent is not anticipated by a prior foreign patent, unless the latter exhibits the invention in such full, clear, and exact terms as to enable any person skilled in the art to practice it without the necessity of making experiments.' " Thus, the court adopted the lex fori not only as to the underlying question of inventive level, but as to the scope of the German patent as well.
} 


\section{Problems}

It is obvious from the foregoing discussion that time limits play an important role within each patent system. Most of these time limits are designed to coerce early disclosure and patenting of inventions. The strictness with which these limits are applied makes it important for every lawyer to know that they exist, and to know that patent counsel must be consulted as soon as possible after the economic decision to patent has been tentatively made. The problems arising from these limitations begin to multiply when more than one patent system is involved; although the patents issued by a country are protected only within its territory, action taken in one country may affect patentability in another. The lawyer who is advising a client with respect to the decision to patent abroad can do so intelligently only if he regards the patenting problems in various countries as a coordinate whole. The following problems are designed to be illustrative rather than exhaustive of the difficulties for which he must be alert.

The following key will be used in diagramming these problems: ${ }^{00}$

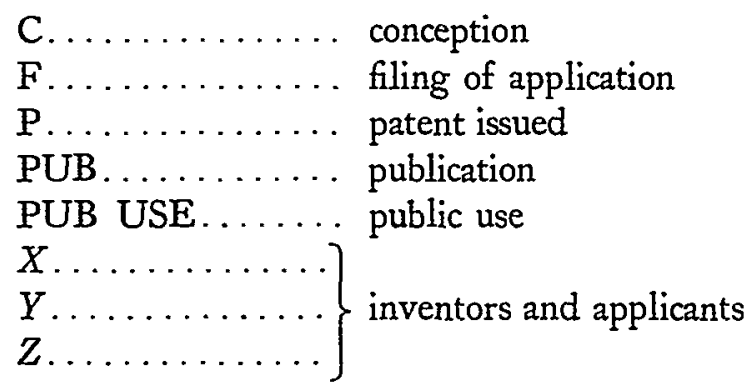

In each case, it will be assumed that an American license for export has been issued, where required, and that conception, use, or publication by several parties is of substantially the same invention.

\section{Conception, filing, and treaty-priority}

Suppose that $X$, a United States national, is first to invent, but $Y$, a German national, conceives and files on the same invention in Germany before $X$ files in the United States. $X$ files in the United States and within one year thereafter also files in Germany. $Y$ files in the United States within one year after his German filing. Placing these events on parallel continuums, the problem appears as follows:

${ }^{D 0}$ The method of diagramming, but not the problems, is borrowed from WoonLING, op. cit. supra note $5 \mathrm{r}$, at 187 et seq. 


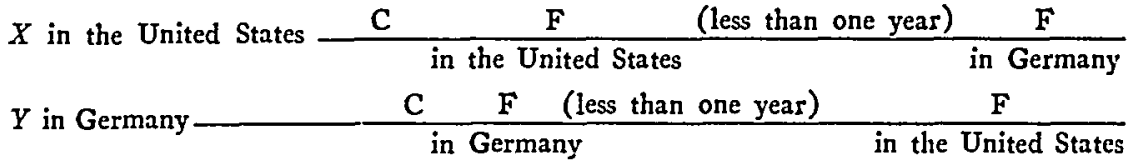

Since both $X$ and $Y$ made their foreign filing in this case within one year after their domestic filing, the treaty priority of the Paris Convention applies to both. Thus, the priority of both of X's applications date from the time he filed in the United States, while both of Y's priority dates are governed by the time of his filing in Germany. It will be remembered that under section $\mathrm{IO} 2(\mathrm{~g})$ of the PCA, priority of conception gives priority of right to patent. Therefore, although $Y$ 's filing date in the United States is given precedence over $X$ 's filing date, $X$ is, nevertheless, entitled to the United States patent by virtue of prior conception. Since $Y$ 's filing date in Germany precedes $X$ 's (even considering $X$ 's German filing as related back to the time of his United States filing), and since first filing rather than first conception gives priority in Germany, ${ }^{91} Y$ is entitled to the German patent.

\section{Foreign filing, danger of domestic unpatentability}

Even if an American inventor obtains a license for the export of his invention, he may lose his rights to a patent in the United States by failing to file in the United States within one year after he files abroad. Thus:

$X$ in the United States $\frac{\mathrm{C} \quad F \text { (more than one year) }}{\text { in Gernany }}$ in the United States

The facts shown do not present an absolute bar, however, on the basis of the wording of section 102(d) of the PCA; the bar applies only if a German patent is issued before the American patent. The difficulty of delaying issue of the German patent has already been noted. ${ }^{92}$ It is particularly important to observe, however, that the requirements of section 102 of the PCA are stated disjunctively, and that $X$ may already have lost his right to a United States patent because of another bar. Since Germany is one of the countries which follows the so-called publication method of patent issue, it is probable that within a few months after the German filing, the application was published. ${ }^{93}$ Thus,

\footnotetext{
${ }^{\text {ox }}$ PatG para. 3 .

${ }^{92}$ See note 67 supra.

${ }^{\text {os }}$ It does not follow automatically that such a publication will be a valid prior reference. As noted earlier, German publication in the Patent Gazette contains only the applicant's name and the title of his invention. Since 1955 , when the practice of printing copies of the complete application was begun, it is probable that a publication sufficient to be anticipatory occurs. See note 26 supra. In Flakice Corp. v. Liquid
} 
the problem may involve another and separate bar of delay:

$X$ in the United States $\frac{C \text { F PUB (more than one year) }}{\text { in Germany }}$

If so, issue of the United States patent will be barred by section ro2(b) of the PCA, even if the foreign patent has not yet been issued.

3. Foreign filing, danger of foreign public use

It has been observed that public use is sufficient to bar issue of a patent in both the United States and Germany if it occurs domestically, while foreign public use is not a bar in either country. ${ }^{94}$ Thus, if $X$ conceives the invention in the United States and files for it there, issue of the patent is not barred even though public use in Germany preceded his conception. It is obvious, of course, that issue of a German patent to $X$ is barred by the prior use under paragraph two of PatG. ${ }^{95}$

The danger of delay in both systems is illustrated by the following situation: Suppose that on January $\mathrm{I}, \mathrm{I957}, X$ conceived an invention, and that on February I, $Y$ made the same conception in Germany. On March I, 1957, $Y$ begins public use of the invention in Germany. On April r, $X$ files for a patent in the United States, and on May I, $Y$ files on the same invention in Germany. Within one year of his United States filing, on March I, 1958, X files on the invention in Germany. Schematically:

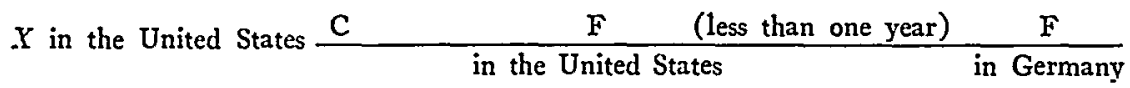

$Y$ in Germany $\quad$ C $\quad$ PUB USE $\quad$ (less than six months) $F$

The right of $X$ to a patent in the United States is, of course, not affected by public use in Germany. In Germany, however, the result is that the invention is probably unpatentable by either $X$ or $Y$. $X$ 's filing date in Germany relates back by treaty priority to the date of his filing in the United States, and his German filing thus gives him the right

Freeze Corp., 130 F. Supp. 471 (N.D. Cal. 1955), defendant cited a German patent as anticipatory of the plaintiff's American patent. The court held the German patent not prior art, since its effective date of issue was subsequent to plaintiff's fling. The publication question, if raised at all, was ignored by the court. Cf. Celanese Corp. of American v. Narrow Ribbon Fabrics Co., 117 F.2d 481, 482 (2d Cir. 1941); also the dictum regarding the logic of viewing foreign patent applications as publications, in In re Tenney, Frank, and Knox, II U.S.P.Q. 348 (1958), cited and discussed in Mediger, supra note 78 , at 569,570 .

os 35 U.S.C. $\$ 102(a)$ and (b) (1952); PatG para. 2.

os The six months grace period cannot apply unless the use was based on the conception by $\mathrm{X}$. 
to the patent as against $Y$, who filed later. $X$ is barred, however, from receiving a German patent because his German filing (even related back) was preceded by $Y$ 's public use. $Y$, of course, is not barred in Germany by the public use because it rested upon his own conception and was followed by filing within six months. ${ }^{90}$

\section{Foreign filing, competing domestic applicants}

It should be noted that the Paris Convention does not make priority by relation back dependent on the issue of a patent by the country of foreign fling. This priority is given if the foreign filing is, or is equivalent to, a regular application under the domestic law of the country where it was filed. ${ }^{97}$ A serious problem under the foreign law may arise if several applicants file for the same invention in the United States.

Suppose that $X$ conceives the invention first, but $Z$ conceives and files in the United States before $X$ files. When $X$ subsequently files in the United States, he has the right to the United States patent, assuming that he has been reasonably diligent. If, within one year of his United States filing, $Z$ files in Germany, $Z$ may be able to obtain a German patent as against $X$, even though $X$ also files in Germany within one year.

$X$ in the United States $\frac{\mathrm{C} \quad \mathrm{F} \text { (less than one year) } \mathrm{F}}{\text { in the United States }} \frac{\mathrm{P}}{\text { in Germany }}$ $Z$ in the United States $\frac{C F \quad \text { (less than one year) F }}{\text { in the United States in Germany }}$

Here, both the application dates in Germany relate back by treaty priority, but $Z$ 's relates back to an earlier date. No decisions have been found in point, but it seems clear that $Z$ would be given preference for the foreign patent under German law because date of conception is irrelevant. As the Paris treaty stands, it is wholly irrelevant whether a patent ever is issued on the application which gives rise to treaty priority elsewhere, and this clear implication in the London version ${ }^{28}$ is

${ }^{80} Y$ has a good argument for issue of the patent to him, on the theory that his right is merely subject to a claim of priority by $X$ which $X$ cannot exercise. It is suggested that complete unpatentability in Germany results, however, from reading PatG para. 3 and $7(3)$ together. Under para. 7 , the date of foreign filing (i.e., in the United States) "is decisive" as to when application is made. Under para. 3, the first applicant is given the "right" to patent. Therefore, $X$ has the "right," and $Y$ does not. The fact that $X$ cannot exercise his right because of another bar does not give $Y$ the "right."

${ }^{87}$ Art. $4 A(2)$ of the treaty, see note 40 supra; consult appendix.

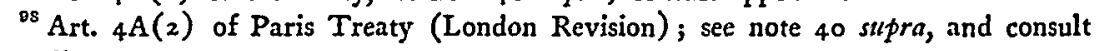
appendix. 
made explicit in the Lisbon revision. ${ }^{99}$ "If $Z$ is advised to file abroad within one year of his unsuccessful domestic filing, he may be able to put himself into a favorable bargaining position with $X$ for license of the domestic patent.

\section{Weakness of treaty priority}

An inventor whose economic planning is based solely on the domestic law of patents runs the risk of barring subsequent issue of a foreign patent because the foreign law may have different or stricter requirements. Suppose that $X$, in the United States, develops his invention diligently, but publishes the idea more than six months before he files in the United States. Subsequently, and within one year after the United States filing, he files in Germany.

$X$ in the United States $\frac{\text { C PUB less than one year) F (less than one year) F }}{\text { in the United States in Germany }}$

Here, $X$ has taken care to file in the United States within one year of his publication, and issue of the American patent is, therefore, not barred. In addition, $X$ has filed abroad within one year, so as to take advantage of the treaty priority rule. Issue of the German patent is, nevertheless, barred, because publication preceded the treaty priority filing date by more than six months, and six months is the maximum grace period allowed under German law. ${ }^{100}$

This danger is even more striking in the reverse situation, because the PCA makes the time periods of the delay provisions run from the date of actual filing. Thus:

$$
X \text { in the United States } \frac{C \text { PUB (less than six months) } F \text { (less than one year) } F}{\text { in Germany in the United States }}
$$

Here, $X$ is clearly entitled to the German patent because his German filing followed publication resting on his own conception within six months. He is also entitled to relate his filing date in the United States back to the German filing date by treaty priority, but under the American statute, this relation back can aid him only with respect to competing applicants. Under section IO2(b) of the PCA, the issue of the United States patent is, therefore, barred. ${ }^{101}$ As noted above, this provision of

${ }^{\text {Bo Art. }} 4 \mathrm{~A}(3)$ of Paris Treaty (Lisbon Revision); see note 40 supra, and consult appendix.

${ }^{100}$ PatG para. 2.

${ }^{302}$ Consult appendix. 
the statute violates the spirit, if not the letter, of the presently effective London revision of the Paris Convention. ${ }^{102}$

This unfortunate tendency of the PCA to fall short of treaty commitments of the United States may also be observed with respect to the treaties of friendship, commerce, and navigation. It will be recalled that these provide for national treatment with respect to the acquisition of patent rights. ${ }^{103}$ Section 104 of the PCA provides, however, that an applicant "may not establish a date of invention by reference to knowledge or use thereof, or other activity with respect thereto, in a foreign country, except as provided in section II9....10: (Section I 19 implements treaty priority if filing in the United States follows foreign filing within twelve months.) The effect of section IO4 of the PCA, therefore, is to prevent any reliance on prior conception in a foreign country. Presumably, such reliance is denied even in the case of compliance with section I I 9 of the PCA, since the latter relates only to foreign "filing." Thus, the earliest date of foreign activity with respect to the invention which will be considered under section $10_{4}$ is the date of foreign filing, although conception must obviously precede filing by an appreciable time. From a strictly legalistic point of view, it may be argued that section 104 of the PCA does not deny national treatment to foreign nationals, since it is also applicable to American nationals whose inventions are made abroad. It is clear, however, that the effective result is to prevent foreign nationals from competing for United States patents on an equal footing with Americans, because most of the inventions of foreign nationals will be made abroad, while relatively few inventions will be made abroad by nationals of the United States.

\section{Weakness of treaty priority, danger of investment}

An easily overlooked danger of reliance on treaty priority arises from the tendency to forget that many states belong to the Paris Convention besides the two in which the applicant is interested. Suppose, for example, that $X$, in the United States, and $Y$, in France, conceive the same invention independently. $Y$ files in France before $X$ files in the United States. $X$ immediately files in Germany, and begins pouring money into the development of plant or equipment under the German patent (or patent application). After $X$ has invested heavily, $Y$ files in Germany also, and does so just before the expiration of a year from his French filing.

\footnotetext{
${ }^{109}$ See note 44 supra. $\quad{ }^{103}$ See text at note 47 supra. $\quad{ }^{104}$ Consult appendix.
} 
\begin{tabular}{lllll}
$X$ in the United States & $\mathrm{C}$ & $\mathrm{F}$ (less than one year) $\mathrm{F}$ & \\
\cline { 1 - 2 } & in the United States & in Germany \\
& $\mathrm{C} \quad \mathrm{F}$ & (less than one year) & $\mathrm{F}$ \\
\hline in France & & in Germany
\end{tabular}

$Y$ is clearly entitled to the German patent as against $X$, because his treaty priority relates his German filing date back to a date earlier than the United States filing of $X . X$ should have been advised not to invest heavily in the foreign patent until at least one year after his filing in the United States, and to do so then only after a search for prior references in the German Patent Office both preceding and subsequent to the date of German filing.

\section{$\mathrm{V}$}

\section{Conclusion}

It should be emphasized that the foregoing problems do not exhaust the dangers which will be encountered in patenting abroad. Many other problems could be suggested, and the problems given could be made more complex by the addition of other parties. The cases discussed, however, are sufficient to illustrate for the international lawyer two major principles in patenting abroad.

First, it is clear that most, if not all, patenting systems place a premium on speed. Because almost all foreign systems give priority of right to the person who files first, mere diligence after conception is not enough. Speed in an absolute sense is essential. The treaty priority given by the Paris Convention is a useful, but far from infallible tool.

Second, the various systems are independent in respect to the protection they give, but they are interdependent with relation to eligibility for patent. Action taken in one country may affect patentability in another. The decision to patent abroad, therefore, cannot be considered separately from the decision to patent domestically. In short, the decision to patent must be viewed as a coordinate whole, and action should be planned only on the basis of specific information about the patent law of all countries in which patenting is contemplated.

It is recognized that these principles are, in a sense, competing rules. The first advises haste, the second urges caution. The function of the lawyer, with the assistance of patent counsel, is to find an intelligent compromise between these principles. 


\section{APPENDIX*}

\section{United States}

U.S. Constitution, art. I \& 8: "The Congress shall have Power ... To promote the Progress of Science and useful Arts, by securing for limited Times to Authors and Inventors the exclusive Right to their respective Writings and Discoveries. ..."

Patent Codification Act, 35 U.S.C. \$ I et seq. (1952)

$\S$ ror "Whoever invents or discovers any new and useful process, machine, manufacture, or composition of matter, or any new and useful improvement thereof, may obtain a patent therefor, subject to the conditions and requirements of this title."

\section{Germany}

Grundgesetz fuer die Bundesrepublic Deutschland, Art. 73: "The Federal Government has exclusive legislative power over ... (9) the protection of industrial rights..."

Patentgesetez rom 5 Mai 1936 (RGBI II II7) in der Fassung der Bekanntmachung vom I 8 . Juli 1953 (BGBl I 623)

Par. I "(I) Patents will be issued for new inventions which permit industrial exploitation. (2) The following are excepted:

I. Inventions the exploitation of which would be contrary to law or to morality;

2. Inventions of foods, luxury goods, medicines, as well as materials which are produced chemically, insofar as the inventions do not concern a specific process for the production of the articles."

Par. 2 "An invention is not considered as new if at the time of the patent application (Par. 26) it has already been described in public, printed publications published within the last one hundred years or if it has already been publicly used in this country, so that use by other persons skilled in the art appears possible

patent, or,

* Translation of the German text is the responsibility of the present writer. 
(b) the invention was patented or described in a printed publication in this or a foreign country or in public use or on sale in this country, more than one year prior to the date of the application for patent in the United States, or

(c) he has abandoned the invention, or

(d) the invention was first patented or caused to be patented by the applicant or his legal representatives or assigns in a foreign country prior to the date of the application for patent in this country on an application filed more than twelve months before the filing of the application in the United States, or

(e) the invention was described in a patent granted on an application for patent by another filed in the United States before the invention thereof by the applicant for patent, or

(f) he did not himself invent the subject matter sought to be patented, or thereafter. A description or use occurring within six months preceding the application for patent will not be considered, if. it rests upon the invention of the applicant or his successor in interest."

Par. 4(2) Notwithstanding the presumption that an applicant is entitled to the grant of a patent, "nevertheless, a later application for patent cannot form the basis of a claim for grant of the patent if the invention is the subject of a patent issued on an earlier application. If this provision applies in part, then the applicant is entitled to issue of the patent witb corresponding limitation."

Par. 4(3) "Nor does the patent applicant have any claim for issue of the patent if the essential contents of his application are taken from the descriptions, drawings, models, appliances or equipment of another without his consent, and the other person has raised an objection on this ground. If the objection causes the withdrawal or rejection of the appli- 
cation, and if the objector applies within one month after notification thereof, then he can demand that the date of the earlier application he set as the date of his application."

(g) before the applicant's invention thereof the invention was made by another who had not abandoned, suppressed, or concealed it. In determining priority of invention there shall be considered not only the respective dates of conception and reduction to practice of the invention, but also the reasonable diligence of one who was the first to conceive and last to reduce to practice, from a time prior to conception by the other."

$\S 103$ "A patent may not be obtained though the invention is not identically disclosed or described as set forth in section 102 of this title, if the differences between the subject matter sought to be patented and the prior art are such that the subject matter as a whole would have been obyious at the time the invention was made to a person having ordinary
Par. 3 "The inventor or his successor in interest has the right to the patent. If several persons have made an invention jointly, then the right to the patent belongs to them jointly. If several persons have made the invention independently of one another, then the right belongs to the one who has first applied for the patent at the Patent Office."

Par. 5 "The person entitled, whose invention has been applied for by an unauthorized person, or one injured by an illegal deprivation, can demand of the patent applicant that he be assigned the claim for issue of the patent. If the application has already resulted in issue of the patent, then he can demand the transfer of the patent from the patentee. The claim can be asserted by an action brought before the expiration of one year after notice of issuance of the patent (par. 35 (I)), later, only if the patentee did not act in good faith in acquiring the patent."

See par. 2 above: "An invention is not considered as new if . . . use by other persons skilled in the art appears possible ..." The German text uses the term Sachverstaendige for the italicized part of the translation, a term which may be translated as "experts" as well as "persons skilled in the art." That a higher degree of skill is contemplated than in the 
skill in the art to which said subject matter pertains. Patentability shall not be negatived by the manner in which the invention was made."
American statute may also be indicated by omission of any term meaning "ordinary" skill.

The following summary indicates some of the most significant similarities and differences in procedure and practice:

United States

Duration of the patent is seventeen years from date patent granted, with varying shorter terms for design and plant patents ( $\$ \S$ I 54-I 73). New improvements on the subject matter may be applied for as independent patents (§ IOI).

Non-residents must appoint an agent for process, and if such an agent cannot be found at the address given, then service may be made by publication ( $\$ 293)$.

Application is made to the Patent Office, and must include patent claims ( III). Examination is made, and if it appears that tbe applicant is entitled, a patent is issued ( $\$$ I 31 ). Applications are kept in confidence by the Patent Office ( $\$$ I22). If, in the examination, it appears that an application would interfere with another patent or application, the interested parties are notified and a hearing held ( $\S$ I35). Administrative or judicial appeals are provided for ( $§$ I $4 \mathrm{I}$, I46).

\section{Germany}

Duration of the patent is eighteen years from the date of application for patent. Improvements may be filed for as independent patents, or as patents of addition which expire with the original patent (par. Io).

Persons with neither domicile nor place of business in the country may only take part in proceedings in the Patent Office and may only assert the rights of protection of a patentee if a patent agent or a lawyer has been appointed as representative in the country (par. 16).

Application is made to the Patent Office, and must include patent claims (par. 26). Examination is made and a decision as to patentability is rendered (par. 28). If the matter is found patentable, the application is published in the Patent Gazette and displayed in the Patent Office; within three months after publication any person may file objection to grant of the patent, stating grounds (par. $30,32)$. Hearing may be had at any time, with or without objection being filed, by the Examining Office; appeals from decisions may be taken (par. 32-34). A decision to grant 
patent is published, and a certificate issued to patentee (par. 35).

Remedies for infringement are federally enforced by civil action ( $\$ 281$ ), and may consist of injunction ( $\$ 283$ ) and damages. Minimum damages are the amount equivalent to a reasonable royalty, and the court may award treble damages ( $\$ 284)$. Either noninfringement or invalidity of the patent of plaintiff may be urged as a defense ( $\$ 282)$. Protection from infringement is given only as to matters specifically claimed in the patent (numerous cases).
Remedies for infringement are enforced through the state courts (par. 51). Injunction may be granted but damages only if the defendant acted intentionally or negligently (par. 47). Proceedings to invalidate a patent may be brought in the Patent Office (par. 17, 13, 37) but invalidity may not be raised as a defense in court action.

The following are the export and national security provisions:

\section{United States}

$\S 184$ "Except when authorized by a license obtained from the Commissioner a person shall not file or cause or authorize to be filed in any foreign country prior to six months after filing in the United States an application for patent or for the registration of a utility model, industrial design, or model in respect of an invention made in this country. . . . The license may be granted retroactively where an application has been inadvertently filed abroad and the application does not disclose an invention within the scope of section 181 of this title" (I8I refers primarily to national security). "The term 'application' when used in this chapter includes applications and any modifications, amendments, or supplements thereto, or divisions thereof." $\$ 185$

\section{Germany}

Par. 30a(i) "If a patent from the Republic is applied for on an invention, which with regard to the security of the Republic should be kept secret, then, upon order, all publication as well as entry in the patent rolls will be omitted." 
prohibits issue of patents where foreign applications have been filed in violation of 184 , and declares such issued patents invalid. $§ I 86$ provides criminal penalties for violation of I 84 .

The following provisions are designed to implement the Paris Convention for the Protection of Industrial Property of 1883 , as revised (see infra):

\section{United States}

$\$ 104$ "In proceedings in the Patent Office and in the courts, an applicant for a patent, or a patentee, may not establish a date of invention by reference to knowledge or use thereof, or other activity with respect thereto, in a foreign country, except as provided in section I I 9 of this title. ..."

§ I I 9 "An application for patent for an invention filed in this country by any person who has, or whose legal representatives or assigns have, previously regularly filed an application for a patent for the same invention in a foreign country which affords similar privileges in the case of applications filed in the United States or to citizens of the United States, shall have the same effect as the same application would have if filed in this country on the date on which the application for patent for the same invention was first filed in such foreign country, if the application in this country is filed within twelve months from the earliest date on which such foreign application was filed; but no patent shall be granted on any application for patent for an invention which had been patented or described in a

\section{Germany}

Par. 27 "A person who claims as decisive the date of a previously filed foreign patent application on the same subject, in accordance with a treaty between states, must state the time and country of the prior application within a period of two months beginning the day after application at the Patent Office (Declaration of priority). Within this period the declaration may be changed. If it is not made in time, the claim of priority for the patent application is forfeited."

Par. 7(I) "The effect of a patent does not operate against a person who, at the time of the application, had already put the invention to use in this country or had made the necessary arrangements for such use ..."

(3) If the patentee has a claim to priority in accordance with a treaty between states or to temporary protection in accordance with the statute of I 8 March I904 (Reichsgesetzbl. S. I4I), concerning protection of inventions, designs, and trademarks at exhibitions, then, instead of the application described in (I), the previously filed foreign application or the 
printed publication in any country more than one year before the actual filing of the application in this country, or which had been in public use or on sale in this country more than one year prior to such filing. No application for patent shall be entitled to this right of priority unless a claim therefor and a certified copy of the original foreign application, specification, and drawings upon which it is based are filed in the Patent Office before the patent is granted, or at such time during the pendency of the application as required by the Commissioner not earlier than six months after the filing of the application in this country. Such certification shall be made by the patent office of the foreign country in which filed..." beginning of the exhibition of the invention is decisive. This does not apply, however, to nationals of foreign states which do not grant reciprocity in this respect."

Paris Convention for the Protection of Industrial Property of 1883 .

The following is the relevant portion of the articles governing patent priority, currently effective as part of the London Revision of 1934 . The text given is that given in the Preliminary Documents for the Lisbon Conference, prepared by the International Bureau of the Industrial Union (Vol. 2 May 1957). Notes record amendments made by the Lisbon Conference, as reported in the Bureau's, Textes adoptés par la Conférence diplomatique de Lisbonne le 3r octobre 1958 (Jan. 1959).

Art. $4 \mathrm{~A}(\mathrm{I})$ "Any person who has duly deposited an application for a patent, or for the registration of a utility model, industrial design or model or trade mark in one of the countries of the Union, or his legal representative or assignee, shall enjoy, for the purposes of deposit in the other countries, a right of priority during the periods hereinafter stated."

NotE: no change.

Art. 4A (2) "Every application which, under the domestic law of any country of the Union, or under international treaties concluded between several countries of the Union, is equivalent to a regular national application, shall be recognized as giving rise to a right of priority." 
Note: amended to read "national legislation" instead of "domestic law," and to read "bilateral or multilateral treaties" instead of "international treaties."

Note: Art. 4A (3) (new) defines a deposit regularly made as any deposit which is effected according to the domestic law of the country where it is made, whatever may be the ultimate result of the application.

Art. $4 \mathrm{~B}$ "Consequently, a subsequent deposit in any of the other countries of the Union before the expiration of these periods shall not be invalidated through any acts accomplished in the interval, either, for instance, by another deposit, by publication or exploitation of the invention, by the putting on sale of copies of the design or model, or by use of the mark, and these acts cannot give rise to any rights of third parties or of personal possession. Rights acquired by third parties before the date of the first application which serves as a basis for the right of priority are reserved in accordance with the domestic legislation of each country of the Union."

Note: no change.

Art. ${ }_{4} \mathrm{C}$ (I) "The above-mentioned periods of priority shall be twelve months for patents and utility models, and six months for industrial designs or models and trade marks."

Note: no change.

Art. ${ }_{4} \mathrm{C}(2)$ "These periods start from the date of deposit of the first application; the day of deposit is not included in the period."

Note: no change.

Art. ${ }_{4} \mathrm{C}$ (3) "If the last day of the period is a dies non or a day when the Office is not open to receive the deposit of applications in the country where protection is claimed, the period shall be extended until the first following working day."

Note: no change.

Note: Art. ${ }_{4} \mathrm{C}(4)$ (new) provides that an application subsequently deposited in a member country shall also be considered as a first application, the date of deposit of which shall be the starting point of periods of priority, if at the time when a right of priority is claimed on the basis of this subsequent application, the original application has been withdrawn, abandoned or refused, and if none of these applications has already served as the basis for a claim to priority. 
Art. $4 \mathrm{D}$ Requires that the applicant make a demand for priority, identifying the date and country of earlier application; specifies proofs required. Each country is allowed to make its own provisions as to when the claim for priority must be made.

NoTE: minor changes respecting identification of prior filing.

Art. $4 \mathrm{E}$ Rules respecting applications for and registration of industrial designs and utility models; priority claims on designs and models.

Note: no change.

Art. $4 \mathrm{~F}$ "No country of the Union may refuse an application for a patent on the ground that it contains multiple priority claims, provided that the application relates to one invention only within the meaning of the law of that country."

NotE: revised to provide that a member country may not refuse a priority or an application on the ground that it contains mutiple priority claims, even if they come from different countries; nor may a member so refuse on the ground that in addition to claiming one or several priorities, it also contains one or more new elements which are not embodied in the claim or claims relied upon for priority. In both cases, however, the application must still relate to only one invention within the meaning of the law of the country of subsequent filing.

Art. $4 \mathrm{G}$ provides for division of applications which relate to more than one invention.

Note: amended to allow applicant to divide on his own initiative. Each country is authorized to make its own regulations respecting division.

Art. $4 \mathrm{H}$ "Priority may not be refused on the ground that certain elements of the invention for which priority is claimed do not appear in the claims formulated in the application in the country of origin, provided that the application documents as a whole disclose such elements in a precise manner."

NotE: no change.

Art. 4 bis provides that patents applied for in different countries are independent. This provision is to be strictly interpreted with respect to such matters as grounds for refusal or revocation, duration and the like.

NoTE: no change.

Art. 4 ter "The inventor has the right to be mentioned as such in the patent." 
Note: no change.

Note: Art. 4 quater (new) provides that the issue of a patent cannot be refused nor a patent declared invalid on the ground that the sale of the product therein described or made by a process therein described is under restriction or limitation by the national law. 